\title{
WHERE ARE ROMANIAN BIOMEDICAL JOURNALS NOW AND WHAT DOES THE FUTURE HOLD FOR THEM? A SCIENTOMETRIC ANALYSIS
}

\section{DAN L. DUMITRASCU}

\author{
Iuliu Hatieganu University of Medicine and Pharmacy Cluj-Napoca, Romania
}

\begin{abstract}
Background and aim. There is a competition between scientific journals in order to achieve leadership in their scientific field. There are several Romanian biomedical journals which are published in English and a smaller number in Romanian. We need a periodical analysis of their visibility and ranking according to scientometric measures.

Methods. We searched all biomedical journals indexed on international data bases: Web of Science, PubMed, Scopus, Embase, Google Scholar. We analyzed their evaluation factors.

Results. Several journals from Romania in the biomedical field are indexed in international databases. Their scientometric indexes are not high. The best journal was acquired by an international publisher and is no longer listed for Romania.

Conclusions. There are several Romanian biomedical journals indexed in international databases that deserve periodical analysis. There is a need to improve their ranking.
\end{abstract}

Keywords: biomedical journals, Romania, scientometrics

\section{Introduction}

There is a large and increasing number of biomedical journals published worldwide. Publishing is a mandatory action of any scientist and is very important for the progress of the humanity. Academics and investigators working in the field of health sciences need to get impact, visibility, authority and recognition thanks to their papers. Therefore scientometry emerged as a science to evaluate the importance of scientific publications (1). Romania is an emerging country trying to increase the impact of its research including the biomedical field. In this county there are a number of biomedical journals, accredited by the Ministry of Education and Research (2). Therefore national scientific publications need to be periodically evaluated in order to assess the place and impact of biomedical research of that nation and to formulate perspective of progress.

The aim of this paper was to evaluate the current state of the Romanian biomedical journals and to assess the future perspectives.

Manuscript received: 03.12.2017

Accepted: 05.01.2018

Address for correspondence: ddumitrascu@umfcluj.ro

\section{Methods}

We looked for the Romanian biomedical journals indexed in the main international databases: Web of Science, PubMed, Scopus, Embase, Google Scholar.

We assessed and compared there rankings, analyzing the factors reposnible for the present scientometric factors. The analysis was carried out in October 2017.

\section{Results}

There are several biomedical journals indexed on Web of Science (WoS) by ISI, formerly under as Thomson Reuters and now Clarivate Analytics. They are displayed on table I.

Unfortunately they do not have high impact factors (IF).

A large number of journals are indexed on PubMed. They are listed in Table II.

Among these 15 biomedical journals, the majority have been included in Index Medicus before 1990 and are in PubMed via Medline. The newer ones have been included via PubMed Central.

Scopus, the other large database that provides 
science indicators, indexes the following biomedical journals from Romania (Table III).

As it may be seen, SCOPUS indexes a higher number of Romanian biomedical journal, increasing their visibility on this data base.

EMBASE is also accommodating a large number of biomedical journals from Romania (see Table IV).

There is a large array of fields covered by EMBASE, Romanian medical journal being quite well represented in this database.

One can see that our journal, Clujul Medical, although not in Web of Science (yet?), is included in several important databases for health sciences. Its coverage is shown in table V.

Google Scholar has also in its database a large number of biomedical journals. Given the easier access to indexation on Google Scholar, we did not analyze their impact on this data base.

Table I. Romanian biomedical journals indexed on WoS.

\begin{tabular}{|l|l|l|l|}
\hline Rank & Full Journal Title & $\begin{array}{l}\text { Total } \\
\text { Cites }\end{array}$ & $\begin{array}{l}\text { Journal Impact } \\
\text { Factor /2016 }\end{array}$ \\
\hline 1 & Journal of Gastrointestinal and Liver Diseases & 1.193 & 1.891 \\
\hline 5 & Medical Ultrasonography & 371 & 1.167 \\
\hline 6 & FARMACIA & 644 & 1.162 \\
\hline 10 & Romanian Journal of Morphology and Embryology & 872 & 0.811 \\
\hline 11 & Digest Journal of Nanomaterials and Biostructures & 1.192 & 0.756 \\
\hline 28 & Notulae Botanicae Horti Agrobotanici Cluj-Napoca & 465 & 0.451 \\
\hline 32 & Optoelectronics and Advanced Materials-Rapid Communications & 827 & 0.412 \\
\hline 34 & JOURNAL OF OPTOELECTRONICS AND ADVANCED MATERIALS & 2.107 & 0.383 \\
\hline 36 & Romanian Biotechnological Letters & 452 & 0.381 \\
\hline 44 & REVUE ROUMAINE DE CHIMIE & 685 & 0.25 \\
\hline 45 & Acta Endocrinologica-Bucharest & 81 & 0.235 \\
\hline 49 & Studia Universitatis Babes-Bolyai Chemia & 103 & 0.148 \\
\hline 50 & Romanian Journal of Legal Medicine & 68 & 0.144 \\
\hline 51 & Revista Romana de Medicina de Laborator & 42 & 0.143 \\
\hline
\end{tabular}

Table II. Romanian biomedical journals indexed on PubMed.

\begin{tabular}{|l|l|l|}
\hline 1. & Bacteriologia, virusologia, parazitologia, epidemiologia (Bucharest, Romania: 1990) & MEDLINE \\
\hline 2. & Chirurgia (Bucharest, Romania: 1990) & MEDLINE \\
\hline 3. & Clujul Medical (1957) (Cluj, Romania) & Not MEDLINE \\
\hline 4. & Current health sciences journal (Craiova 2013) & Not MEDLINE \\
\hline 5. & Europe's Journal of Psychology (Bucharest) & Not MEDLINE \\
\hline 6. & Germs (National Institute of Infectious Diseases Matei Bals) & Not MEDLINE \\
\hline 7. & Journal of Gastrointestinal and Liver Diseases (Romanian Society of Gastroenterology and Hepatology) & MEDLINE \\
\hline 8. & Journal of medicine and life (Universitatea de Medicină și Farmacie "Carol Davila"-București) & MEDLINE \\
\hline 9. & Medical Ultrasonography (Romanian Society of Ultrasonography in Medicine and Biologie) & MEDLINE \\
\hline 10. & Mædica (Romanian Physician College) & Not MEDLINE \\
\hline 11. & Pneumologia (Romanian Society of Pneumology) & MEDLINE \\
\hline 12. & Revista Medico-Chirurgicala a Societatii de Medici si Naturalisti din Iasi & MEDLINE \\
\hline 13. & Romanian Journal of Morphology and Embryology & MEDLINE \\
\hline 14. & Romanian Journal of Ophthalmology (Romanian Society of Ophtalmology) & MEDLIN. \\
\hline 15. & Roumanian Archives of Microbiology and Immunology (Institute Ion Cantacuzino) & MEDLINE \\
\hline
\end{tabular}


Tabe III. Romanian biomedical journals indexed in Scopus.

\begin{tabular}{|c|c|}
\hline TITLE & $\begin{array}{l}\text { SJR / SCIMAGO } \\
\text { JOURNAL RANK }\end{array}$ \\
\hline Journal of Gastrointestinal and Liver Diseases & 0.522 \\
\hline GERMS & 0.414 \\
\hline Medical Ultrasonography & 0.379 \\
\hline Journal of medicine and life & 0.284 \\
\hline Romanian Journal of Morphology and Embryology & 0.276 \\
\hline Farmacia & 0.261 \\
\hline Romanian journal of internal medicine $=$ Revue roumaine de medecine interne & 0.244 \\
\hline Chirurgia & 0.230 \\
\hline AACL Bioflux & 0.228 \\
\hline Revista Medico-Chirurgicala a Societatii de Medici si Naturalisti din Iasi & 0.198 \\
\hline Clujul Medical & 0.190 \\
\hline Studia Universitatis Vasile Goldis Arad, Seria Stiintele Vietii & 0.179 \\
\hline Romanian Journal of Legal Medicine & 0.167 \\
\hline Roumanian Archives of Microbiology and Immunology & 0.166 \\
\hline Biharean Biologist & 0.147 \\
\hline Gineco.eu & 0.145 \\
\hline Pneumologia & 0.145 \\
\hline Revista Romana de Medicina de Laborator & 0.143 \\
\hline Acta Endocrinologica & 0.127 \\
\hline Romanian Journal of Neurology/ Revista Romana de Neurologie & 0.124 \\
\hline Otorinolaringologia & 0.121 \\
\hline Romanian journal of ophthalmology & 0.116 \\
\hline Romanian Journal of Anaesthesia and Intensive Care & 0.114 \\
\hline Human and Veterinary Medicine & 0.112 \\
\hline Annals of the Romanian Society for Cell Biology & 0.105 \\
\hline Journal of Translational Medicine and Research & 0.105 \\
\hline Revista Romana de Bioetica & 0.105 \\
\hline Therapeutics, Pharmacology and Clinical Toxicology & 0.101 \\
\hline Analele Universitatii din Oradea, Fascicula Biologie & - \\
\hline
\end{tabular}

Table IV. Romanian biomedical journals indexed in EMBASE.

\begin{tabular}{|l|l|}
\hline ACTIVE EMBASE JOURNAL TITLES (MAY 2017) & PUBLISHER \\
\hline Archives of the Balkan Medical Union & Celsius Publishing House \\
\hline Chirurgia (Romania) & Editura Celsius \\
\hline Clujul Medical & Universitatea de Medicina si Farmacie Iuliu Hatieganu \\
\hline Farmacia & Romanian Society for Pharmaceutical Sciences \\
\hline GERMS & European Academy of HIV/AIDS and Infectious Diseases \\
\hline Gineco.eu & Versa Puls media Network \\
\hline Journal of Gastrointestinal and Liver Diseases & Romanian Society of Gastroenterology \\
\hline Medical Ultrasonography & Societatea Romana de Ultrasonografie in Medicina si Biologie \\
\hline Obstetrica si Ginecologie & Romanian Society of Obstetrics and Gynecology \\
\hline Pneumologia & Romanian Society of Pneumology \\
\hline Romanian Journal of Anaesthesia and Intensive Care & Editura Clasium \\
\hline Romanian Journal of Internal Medicine & Editura Academiei Romane \\
\hline Romanian Journal of Legal Medicine & Romanian Legal Medicine Society \\
\hline Romanian Journal of Morphology and Embryology & Editura Academiei Romane \\
\hline Romanian Journal of Neurology/ Revista Romana de Neurologie & Editura Medicala \\
\hline Therapeutics, Pharmacology and Clinical Toxicology & Romanian Society of Pharmacology, Therapeutics and Clinical Toxicology \\
\hline Timisoara Medical Journal & Victor Babes University of Medicine and Pharmacy \\
\hline
\end{tabular}


Table V. Databases indexing Clujul Medical.

\begin{tabular}{|l|l|l|}
\hline Database & Date of first indexing & Covered interval \\
\hline EBSCO & 2008 & $1 / 2009-$ present \\
\hline SCOPUS & 2014 & $\begin{array}{l}1 / 2014-\text { present } \\
1973-1990\end{array}$ \\
\hline PubMed & 2015 & $1 / 2013-$ present \\
\hline EMBASE* & 2016 & $\begin{array}{l}1 / 2016-\text { present } \\
1957-1990\end{array}$ \\
\hline $\begin{array}{l}\text { Web of Science* } \\
\text { All Databeses }\end{array}$ & 2016 & $1 / 2013-$ present \\
\hline $\begin{array}{l}\text { CAB Abstracts / } \\
\text { Global Health }\end{array}$ & 2017 & $1 / 2017-$ present \\
\hline Google Scholar & - & $2010-$ present \\
\hline
\end{tabular}

\section{Discussion}

There is an important number of biomedical journals published din Romania. They are mainly issued by medical universities of by research institutes or scientific societies. All the indexed journals from international databases are in English. They are almost all open access. Most of them publish for free, other have low publication fees, making the submission of papers to these journals attractive. Several international authors submit and publish in Romanian journals.

On the other hand, Romanian authors do not publish only in Romania, but publish in other, often highly ranked international journals, given the need of recognition of visibility of any scientist.

There are also some Romanian biomedical journals published in Romanian (almost all with English abstracts) but given their national circulation, they were not analyzed in this paper. One can observe that most of the biomedical publications of his country have low Impact Factor according to WoS. The explanation is given by the fact that most of the journals are rather "young", with recent presence on the internet and have therefore inherited a low visibility. But the visibility tends to increase in recent years.

The best Romanian medical journal, Journal of
Cellular and Molecular Medicine, has been acquired by an international publisher; therefore it is no longer listed as a Romanian journal. Many other Romanian journals receive offers to be purchased by international publishers and it is to expect that in the future other WoS indexed journals will lose the national character.

Three WoS journals have lost their indexation in the last five years because of loss of scientific interest or because of high rates of self citations.

Journals of medical universities have difficulties in improving their ranking because one of their remits is to publish a number of articles of local importance, which deserve however to be published, and because of the lack of a precise profile. Such journals accept largely papers form their own universities, thus having lower diversity. They also publish epidemiological data or single center studies with local importance. The journals of the scientific societies do better in the perspective of improving their ranking.

\section{Conclusions}

There is a substantial number of biomedical journals in Romania that are open access, frequently without publication fee and indexed in the main international data bases. However their impact has to be improved.

\section{Acknowledgment}

Special thanks go to Ms Ioana Robu, $\mathrm{PhD}$ for performing the scientometric research.

\section{References}

1. Thonon F, Boulkedid R, Delory T, Rousseau S, Saghatchian M, van Harten W, et al. Measuring the outcome of biomedical research: a systematic literature review. PLoS One. 2015 2;10(4):e0122239. doi: 10.1371/journal.pone.0122239.

2. Unit for Higher Education Financing and Research. Evaluation of scientific journal. Available from: https://uefiscdi.ro/ scientometrie-reviste 